\title{
Assessment of Chicken Production and Productive Performance in Pawe District, Beneshangul Gumuz Regional State, Ethiopia
}

\author{
Dejene Teshome Biratu \\ Department of Animal Sciences, College of Agriculture and Natural Resource, Assosa University, Assosa, Ethiopia
}

Email address:

dteshome19@gmail.com

\section{To cite this article:}

Dejene Teshome Biratu. Assessment of Chicken Production and Productive Performance in Pawe District, Beneshangul Gumuz Regional State, Ethiopia. American Journal of Management Science and Engineering. Vol. 6, No. 1, 2021, pp. 1-10.

doi: 10.11648/j.ajmse.20210601.11

Received: December 29, 2020; Accepted: January 15, 2021; Published: March 10, 2021

\begin{abstract}
The study was conducted with the overall objective to assess of chicken production systems and identify the productivity performance related to chicken production under village/traditional production system in pawe district of Beneshangul Gumuz Regional State, Ethiopia. A total of 80 respondents were purposively selected from four purposively selected kebeles in the study areas based on the accessibility and the potential in chicken production. All the collected data were analyzed using SPSS version of 20. Results of the study revealed that the average flock size of local chickens was (13.8 \pm $0.20)$ per household in the study areas. The average age at first egg laying for the local chickens was (6.18 \pm 0.024 month). The survey indicated that the average egg production of the local chicken breeds was $(60 \pm 0.123$ eggs per hen per year). The study also revealed that the average number of eggs set for brooding/incubation was $10.65 \pm 0.03$ per hen, from which relatively fair percentage of chicks $(81.50 \%)$ was hatched from local chickens. High proportion of chicken mortality up to age of 8 weeks was reported which might indicate high prevalence of chickens diseases and predators. The study revealed that majority of the respondents practice traditional scavenging system of chicken production. The major diseases of chicken in the study areas were New castle disease, Fowl typhoid, Infectious bronchitis, Gumboro and Marek's diseases in order of their importance. Thus, the major constraints related to poultry production should be alleviated to scale out through improve overall management chicken with the distribution of improved chicken breeds for producers to better the productivity of chickens in the study areas.
\end{abstract}

Keywords: Local Chickens, Chicken Production, Chicken Productivity

\section{Introduction}

In Ethiopia chickens are the most widespread and almost every rural family owns chickens, which provide a valuable source of family protein and income [28]. Ethiopia has 60.51 million chickens, among which indigenous chicken constitute $94.33 \%$ and the remaining $2.47 \%$ is exotic and $3.21 \%$ hybrid chicken [5]. The majorities (99\%) of these birds are maintained under a traditional system with little or no inputs for housing, feeding or health care. The most dominant chicken types reared in this system are local ecotypes, which show a large variation in body position, plumage color, comb type and productivity [9].

Rural poultry in Ethiopia represents a significant part of the national economy in general and the rural economy in particular and contributes $98.5 \%$ and $99.2 \%$ of the national egg and chicken meat production, respectively [1, 11]. However, the economic contribution of the sector is not still proportional to the huge chicken numbers, attributed to the presence of many production, reproduction and infrastructural constraints. About $99 \%$ of chicken owners of North- eastern Ethiopia provided supplementary feed to village birds once per day, mainly during feed shortage seasons [9]. The greater part of the feed for village birds is obtained through scavenging, which includes; the household cooking waste, cereal and cereal by-products, roots and tubers, oilseeds, trees, shrubs, fruits and animal proteins [26]. The amount \& availability of scavenging feed resource base (SFRB) per bird are significantly dependent on season, household grain availability, the time of grain sowing and harvesting and household flock size [24]. 
According to the data obtained from BGRS-ANRD office (2017), there were around 1.62 million chicken populations in BGRS, accounting to $2.9 \%$ of the national chicken population. Metekel administrative zone, where the study district is found, accounts to 409, $863(25.3 \%)$ of the regional chicken population (BGRS-ANRD 2017).

It is difficult to design and implement chicken-based development programs that benefit rural people without understanding village chicken production and marketing systems [20]. Understanding of village chicken functioning and marketing structure are a prerequisite for developing market opportunities for rural households and could be used to inform policymakers and development workers in considering the commercial and institutional environment in which village chicken keepers have to operate [10].

\subsection{Statement of the Problem and Research Gaps}

Pawe district of Metekel zone is one of the top producers of chickens. It is believed that the nutritional status and income levels of rural and town populations could be enhanced through productivity of chicken populations. However, the current production and productivity of chickens in the pawe district have not well investigated and documented even in Beneshangul Gumuz in general. Therefore, it is a high time and urgent need to investigate the current production and productivity performance of chickens in pawe district. Based on the above-mentioned facts and research gaps, this research is initiated with the following general and specific objectives.

\subsection{Objectives}

\subsubsection{General Objective}

To assess chicken production system and productivity performance in Pawe District, Beneshangul Gumuz Regional State, Ethiopia

\subsubsection{Specific objectives}

1) To study the current on-farm production of chickens under village production system in the study area

2) To study the current productivity performance of chickens in the study area

\section{Materials and Methods}

\subsection{Description of the Study Areas}

The study was conducted at Pawe district found in Metekel administrative zone of Beneshangul Gumuz Regional state (BGRS), located at $11^{0} 09^{\prime} \mathrm{N}$ latitude and $36^{\circ} 03^{\prime} \mathrm{E}$ longitudes in the North-Western part of the country. The study district shared boarders with Dangur district in North, Mandura district in South, Dangur and Mandura district in west and Amhara Region in the East. According to BGRS-BoANRD (2017), the study district has an agricultural human population size of 41,162 (21,186 male and 19,976 female) and the total human population was estimated to be 59,127 (30,041 males and 29,113 females). The population density is estimated to be 87.68 people per square kilometer. The study district has a total of 20 rural kebeles, from which 3 are urban (Felege, Selam and Mender 7) and 18 are rural kebeles. From the total human population, 85\% were rural community and $15 \%$ were urban dwellers (BGRSBoANRD, 2017). Almu, the administrative and commercial center of the district, is found at about 340 and $548 \mathrm{~km}$ from Assosa, the capitals of Beneshangul-Gumuz Regional State and Addis Ababa, respectively.

The study district has a total land area of $5184.2 \mathrm{~km}$ square. The average altitude of the study district is estimated to be 1120 meters above sea level. The total average annual rainfall is estimated to be $1578 \mathrm{~mm}$ and the rainfall has a mono-modal pattern which extends from late May to early November. It has an average temperature $24.4^{\circ} \mathrm{C}$ with minimum and maximum annual temperature of $16.3^{\circ} \mathrm{C}$ and $32.6^{\circ} \mathrm{C}$, respectively (BGRS-BoANRD, 2017). Livestock is considered as an important component of the prevailing croplivestock mixed farming systems of the study district. Small holder farmers of the study area owned various livestock species such as; cattle, sheep, goat, chicken and equines. According to BGRS-BoANRD (2017), the study district is reported to have a total population of 67,171 for cattle, 316,890 for sheep, 15,362 for goats, 491 for donkeys, 568 for mules and 23,017 for chicken. The study district was categorized as one of the administrative districts of Metekel administrative zone of Beneshangul Gumuz Regional state (BGRS) known to have highest potential for crop and livestock production. Crop production is highly related to village chicken production of the study district with high seasonal fluctuation of feeds availability, high prevalence of disease and other production and marketing constraints (BGRS-BoANRD, 2017).

Sorghum, soy bean, maize, Finger millet, sesame, groundnut, Mango, pepper and vegetables were the common crops grown. Most households produced two or more of the mentioned crops. Cattle, goats, sheep, and donkeys are the types of livestock raised. About 57 percent of the total households in the study sites keep chicken.

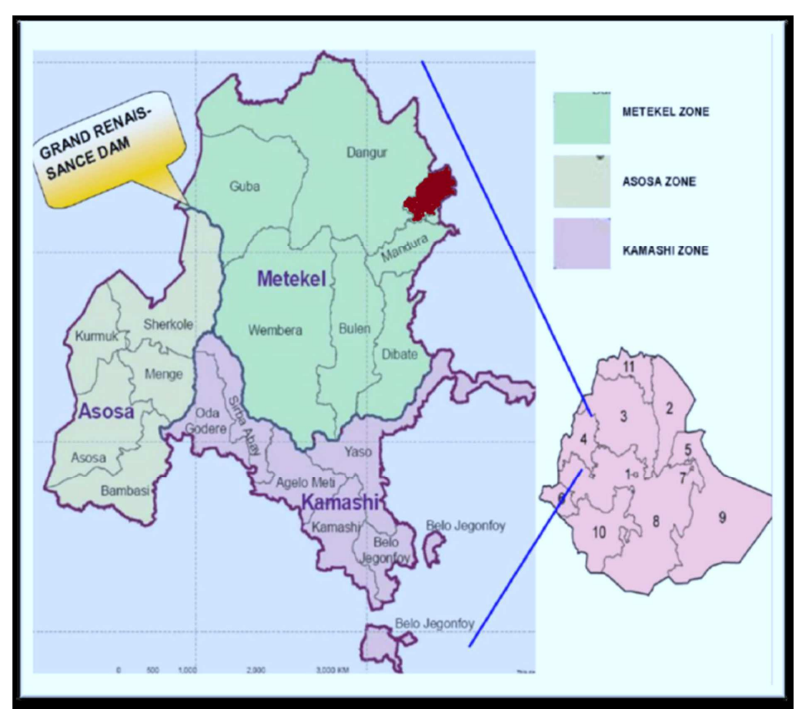

Figure 1. Location of the study district Source: BGRS, BoANRD, 2017. 


\subsection{Study Methodology}

\subsubsection{Sample Size Determination}

The total household included in the study areas was determined according to the formula given by Yemane (1967) for homogenous experimental material, with 95 percent confidence level.

$$
\mathrm{n}=\frac{\mathrm{N}}{1+\mathrm{N}(\mathrm{e})^{2}}=\frac{100}{1+100(0.05)^{2}}=80
$$

Where, $\mathrm{n}=$ designates the sample size

$\mathrm{N}=$ designates total number of households

$\mathrm{e}=$ designates maximum variability or margin of error $=5 \%$ (0.05)

$1=$ designates the probability of the event occurring

Accordingly, the sampled household in the study area were unequal proportion of sample size household in each kebeles (a total of 80 households), was selected.

Table 1. Sample size determination.

\begin{tabular}{lll}
\hline Name of selected kebeles & $\begin{array}{l}\text { Total number of households } \\
\text { having local chicken }\end{array}$ & $\begin{array}{l}\text { Sampled } \\
\text { households }\end{array}$ \\
\hline Mender 17 & 25 & 20 \\
Mender 23 & 27 & 22 \\
Mender 49 & 25 & 20 \\
Mender 134 & 23 & 18 \\
Total sample households & - & 80 \\
\hline
\end{tabular}

\subsubsection{Household Selection and Sampling Techniques}

Four kebeles (Mender 17, Mender 23, Mender 49 and Mender 134) were purposively selected based on the potential for population of chickens and accessibility of the area. A total of 80 households were purposively selected in the pawe district.

\subsubsection{Data Sources and Collection Methods}

Both primary and secondary data was used for this study. Secondary data (like total number of chickens, mortality rate, health care, etc.) were obtained from the Pawe of Livestock and Fishery Development office annual and quarterly reports. Primary data were collected by formal interview methods using semi structured questionnaires.

\subsubsection{Data Analysis}

Qualitative data was collected and all the data collected were entered in to Microsoft excel spreadsheet and analyzed using Statistical package for social science (SPSS) version 20. Then descriptive statistical tools such as percentage, mean and standard error were used to present the data.

\section{Results and Discussion}

\subsection{Socio-economic Characteristics}

The household characteristics of interviewed village chicken owner households were presented in Table 2. Among the overall households, the majority of the households $(80.0 \%)$ were male-headed while $(20.0 \%)$ female-headed households. The most dominant age group within the household heads was younger age between 15- 30 years (72.5\%), followed by mid age 31-60 year (16.25\%), elderly $(23.75 \%)$ and above 60 years $(3.75 \%)$. This indicated that about $96.25 \%$ of the respondents were within the productive age category (15-60 years), which has significant contribution in chicken production where the demand for labour is high. The overall average family size in sampled households was $5.21 \pm 0.08$. These values were comparable to the national average 5.20 persons (CSA, 2003).

The majority $(72.5 \%)$ of the respondents were found to be literate while $27.5 \%$ of them were illiterate. This is revealed that the higher proportion of educational levels of the household heads in the study area have a vital role in adopting and promoting new technologies and to examine the available information in the production of chicken.

Table 2. Demographic characteristics of the sampled house hold heads.

\begin{tabular}{|c|c|c|c|c|c|}
\hline \multirow{2}{*}{ Parameters } & \multicolumn{4}{|l|}{ Pawe district } & \multirow{2}{*}{$\begin{array}{l}\text { Overall mean } \\
(\mathrm{N}=\mathbf{8 0})\end{array}$} \\
\hline & Mender $17(\mathrm{~N}=\mathbf{2 0})$ & Mender 23/45 $(\mathrm{N}=22)$ & Mender $49(\mathrm{~N}=20)$ & Mender $134(\mathrm{~N}=18)$ & \\
\hline \multicolumn{6}{|c|}{ Household heads (\%) } \\
\hline Male & 85.00 & 72.70 & 75.00 & 88.90 & 80.00 \\
\hline Female & 15.00 & 27.30 & 25.00 & 11.10 & 20.00 \\
\hline \multicolumn{6}{|c|}{ Age group $(\%)$} \\
\hline $15-30$ & 80.00 & 77.30 & 60.00 & 72.22 & 72.50 \\
\hline $31-60$ years & 15.00 & 18.15 & 35.00 & 27.78 & 23.75 \\
\hline \multicolumn{6}{|c|}{ Education level (\%) } \\
\hline Illiterate & 23.70 & 23.70 & 30.00 & 33.30 & 27.68 \\
\hline Literate & 76.3 & 76.3 & 70 & 66.7 & 72.32 \\
\hline Family size & $5.18 \pm 0.08$ & $5.34 \pm 0.08$ & $5.57 \pm 0.08$ & $4.74 \pm 0.08$ & $5.21 \pm 0.08$ \\
\hline
\end{tabular}

\subsection{Purposes of Chicken Rearing and Chicken Ownership in Household in the Study Areas}

Farmers raise chickens for the purposes of income generation, home consumption, Cultural value, to entertain guests and for breeding. The results of the study revealed that
$45.1 \%, 18.7 \%, 13.6 \%, 12.6 \%$ and $10.1 \%$ of the respondents keep chicken for income generation, home consumption, Cultural value, to entertain guests and for breeding, respectively (Table 3 ).

The survey results as well as the discussion made with key informant groups of the study sites indicates that, either 
slaughtering or holding certain birds for sacrifice or healing ceremony is not practiced. This indicates that the main objective of poultry keeping is to sell the birds and egg and utilize the eggs for home consumption. Thus, the poultry make considerable contribution to improve the family income and protein needs of the rural farmers as reported by many authors in different countries [27].

Among eggs produced, about 68.75, 20.0 and $11.25 \%$ were used for sale, hatching, and home consumption, respectively. The demand for egg in study area might have made the farmers to sell the largest proportion (68.7\%) of eggs produced.

The study also indicated that $48.75 \%$ of surveyed household's chicken production was practiced by women and in $27.50 \%$ of surveyed households, it is practiced by whole family members (women, men and children) (Table 4). But in the remaining $8.75,5.00$ and $10.00 \%$ of surveyed households chickens was run by children, men and both women and children, respectively. This result indicates that higher proportion of women participated on chicken production as compared to men. This result is concurred with the report of that reported $51.7,32.5$ and $15.8 \%$ of the village chicken production owned by women, children and men, respectively, in Chelliya district [4]. But disagreement with some result of that reported $92.4 \%$ of the village chicken production practiced by both women and children followed by men (husband) $7.6 \%$ in mid Rift Valley of Oromia [22].

Table 3. The Purpose of chicken and eggs rearing in household in the study areas.

\begin{tabular}{|c|c|c|c|c|c|}
\hline \multirow{2}{*}{ Variables } & \multicolumn{4}{|l|}{ Pawe district } & \multirow{2}{*}{$\begin{array}{l}\text { Overall mean } \\
(\mathrm{N}=\mathbf{8 0})\end{array}$} \\
\hline & Mender $17(\mathbf{N}=\mathbf{2 0})$ & Mender 23/45 $(\mathrm{N}=22)$ & Mender $49(\mathrm{~N}=20)$ & Mender $134(\mathrm{~N}=18)$ & \\
\hline \multicolumn{6}{|c|}{ Purpose of keeping chicken (\%) } \\
\hline Generate income & 45.0 & 45.4 & 40.0 & 50.0 & 45.1 \\
\hline Consumption & 20.0 & 18.2 & 20.0 & 16.7 & 18.7 \\
\hline Hatching/Breeding & 10.0 & 9.1 & 10.0 & 11.1 & 10.1 \\
\hline Cultural/religious & 10.0 & 18.2 & 15.0 & 11.1 & 13.6 \\
\hline To entertain guests & 15.0 & 9.1 & 15.0 & 11.1 & 12.6 \\
\hline Hatching & 25.00 & 18.20 & 20.00 & 16.67 & 20.00 \\
\hline Sale for income & 60.00 & 68.20 & 75.00 & 72.22 & 68.70 \\
\hline Home consumption & 15.00 & 13.64 & 5.00 & 11.11 & 11.30 \\
\hline
\end{tabular}

Table 4. Chicken ownership in household in the study areas.

\begin{tabular}{lll}
\hline Chickens Ownership in HH (\%) & \\
\hline Woman & 39 & 48.75 \\
Men & 4 & 5.00 \\
Children & 7 & 8.75 \\
All family members & 22 & 27.50 \\
women and children & 8 & 10.00 \\
\hline
\end{tabular}

\subsection{Flock Size and Flock Structure of Chicken}

The average flock size of local chickens per household in the study was (13.8 \pm 0.20$)$ (Table 5). The large number of chickens per household might be due to high population growth and shortage of grazing land for other livestock production. The respondents also reported that they engaged in chicken rearing or having more number to get more income from selling of chicken and chicken product for buying grain for the family consumption, cover school fee, paying land tax, purchasing cloth for their family and other expense. The present report on chicken flock size is by far higher than the flock size of 8.53 chickens per household reported at Halaba district of southern Ethiopia, but it is lower than the report that reported 19 birds per household in Sudan [11].

Table 5. Chicken flock size and structure of the study areas.

\begin{tabular}{|c|c|c|c|c|c|c|}
\hline \multirow{2}{*}{ Kebeles } & \multicolumn{5}{|c|}{ Chicken flock size and structure $($ Mean $\pm \mathrm{SE})$} & \multirow{2}{*}{ Over all mean } \\
\hline & Hens & Cocks & Pullets & Cockerel & Chicks & \\
\hline Mender 17 & $3.4 \pm 0.40$ & $0.8 \pm 0.20$ & $1.6 \pm 0.15$ & $0.7 \pm .02$ & $6.4 \pm 0.42$ & $12.9 \pm 0.24$ \\
\hline Mender 23 & $3.7 \pm 0.30$ & $1.4 \pm 0.11$ & $2.0 \pm 0.18$ & $0.9 \pm 0.03$ & $6.7 \pm 0.45$ & $14.7 \pm 0.43$ \\
\hline Mender 49 & $3.2 \pm 0.01$ & $1.0 \pm 0.22$ & $2.9 \pm 0.23$ & $1.0 \pm 0.01$ & $4.6 \pm 0.4$ & $12.7 \pm 0.18$ \\
\hline Mender 134 & $4.3 \pm 0.07$ & $1.6 \pm 0.02$ & $2.3 \pm 0.21$ & $1.0 \pm 0.01$ & $5.8 \pm 0.43$ & $15.0 \pm 0.15$ \\
\hline Total & $3.6 \pm 0.20$ & $1.2 \pm 0.14$ & $2.2 \pm 0.19$ & $0.9 \pm 0.02$ & $5.9 \pm 0.43$ & $13.8 \pm 0.20$ \\
\hline
\end{tabular}

\subsection{Management Systems of Chicken in the Study Areas}

\subsubsection{Chicken Production Systems of the Study Areas}

In the study areas, majority of the farmers $(92.6 \%)$ practice the traditional scavenging system of chicken production. The results of the study (Figure 2) showed that the dominant chicken production system was a free-range scavenging or extensive type, utilizing various feed sources searching by their own in the field, with conditional feed supplementation. During the rainy season, mostly the chickens feed different 
types of insect, worms and leaves of different vegetables and grasses sown at the garden because there is shortage of grain yet for human being. The input offered for the chickens and the output harvested is low. The quality and quantity of the products obtained from scavenging system of production is also poor compared to the semi-intensive chicken production systems.

From total sample size, about 92.6 and $7.4 \%$ of the respondents kept chickens in extensive and semi-intensive in study area, respectively. This implies that farmers in the study areas are going to change and improve chicken production system and management practices like provision of improved health care, commercially formulated feed and separate poultry house. This proportion is almost nearest to the report of some reporter who reported $83.3 \%$ and $16.7 \%$ of the respondents reared chickens in extensive and semiintensive systems, respectively [13]. Some reporter also reported that the type of management system is commonly extensive (71.66\%), semi-intensive (23 to 33\%) and intensive (5\%) in Enebsie Sar Midir Woreda, Eastern Gojjam [14]. Reported that in South west and South part of Ethiopia also similar with current finding are the management system provided for chickens was extensive $(71.6 \%)$ and semiintensive (28.4\%) [17].

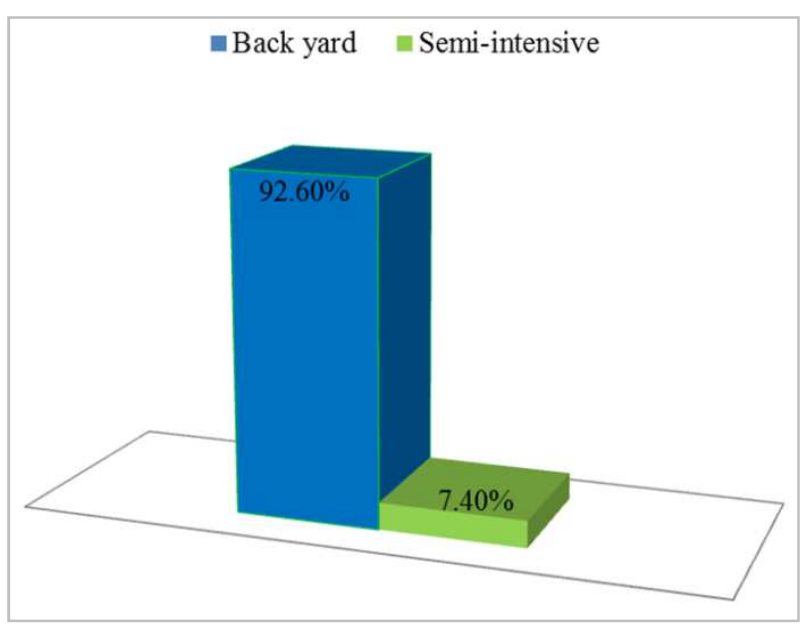

Figure 2. Chickens production systems of the study area.

\subsubsection{Feed Resources and Feeding Practices of Chickens}

The major feeds and feeding practices of chickens and the methods of provision of supplementary feeds in the study areas are summarized in Tables 6 and 7. Result of the study revealed that about $82.5 \%$ of the respondents practiced scavenging with additional supplements and $10.0 \%$ use only scavenging with no additional feed supplements. From the total sample size, only $7.5 \%$ of the respondents provide homemade feeds for their chickens. The one report that reported $97.8 \%$ of the respondents were using scavenging with additional supplements, $2.8 \%$ using purchased feed and $2.2 \%$ using only scavenging was in line with the current report [7]. Additional report also reported that $83 \%$ of the farmers use scavenging and supplement, and $17 \%$ use only scavenging in Ethiopia [6, 19]. But the present finding is at par with the report that reported about 55, 33 and $12 \%$ households involved scavenging only, scavenging and grain supplementation and provided refusals as supplementary feeds, respectively [29]. In the study districts, about $92.6 \%$ (Sorghum and maize) and $7.4 \%$ (Maize and wheat) of the farmers reported that they provided locally available cereal grains as supplementary feed for chickens. But the amount of supplement varies depending on seasons of the year and the quantity and availability of the resources at the household level. Similarity was with reported that $95 \%$ of the farmers in east Shewa offer wheat and maize as supplement [7]. Regarding feeding frequency, 62.5, 27.5 and $10.0 \%$ of the respondents offered supplements for chickens twice a day (morning and afternoon/evening), three times per day (morning, afternoon and evening) and once per day (morning only), respectively. This result is in line with that reported in the report of surveyed household in Gomma offer supplement twice a day (morning and afternoon), three times per day (morning, afternoon and evening) and once per day, respectively $[25,26]$. Additional report also reported that $27.78,18.89,34.44$ and $7.78 \%$ of the farmers provided supplement three times per day (morning, afternoon and evening), twice per day (morning and evening), once per day (morning only and afternoon only) and no feeding, respectively [3]. About 70\% of the surveyed households offer each ingredient of grain supplement alone and $30 \%$ of them provided a mixture of different grain supplement in the study area (Table 6).

Table 6. Feed resources and feeding systems of chicken.

\begin{tabular}{lll}
\hline & \multicolumn{2}{l}{ Study Area } \\
\cline { 2 - 3 } Variables & \multicolumn{2}{l}{ Pawe district } \\
\cline { 2 - 3 } & Number & Percent \\
\hline Feeding practices of chickens & 8 & 10.0 \\
Scavenging only & 66 & 82.5 \\
Scavenging with supplement & 6 & 7.5 \\
Homemade feed & & \\
Time of feed supplements & 8 & 10.0 \\
Morning only & 13 & 16.25 \\
Morning and evening & 37 & 46.25 \\
Morning and afternoon & 22 & 27.5 \\
Morning, afternoon and evening & & \\
Types of grain used for supplement & 26 & 32.50 \\
Maize & 17 & 21.25 \\
Maize and wheat & 37 & 46.25 \\
Sorghum and maize & & \\
Frequency of supplementing per day & 8 & 10.0 \\
Once & 50 & 62.5 \\
Twice & 22 & 27.5 \\
Three times & & 30.0 \\
Form of grain supplemented & 24 & 70.0 \\
Mixture of different ingredient/cereals & 56 & \\
Each ingredient/cereals alone & & \\
\hline
\end{tabular}

As indicated in table 7 , majority $(76.2 \%)$ of the households in the study district provide supplementary feeds by throwing on the ground. Group feeding is practiced by most ( $85.0 \%)$ of the surveyed households. Only 5 and $10 \%$ of the surveyed households separate chicken by sex and age, respectively during supplementary provision. Group feeding has its own effect on the growth and productivity performance of very young chickens and weak layers. System of feeding for the 
present study area resembles the report that reported $91.1 \%$ of the respondents provided supplementary feeds by throwing on the ground to feed in groups without age separation [13]. Additional report also reported $94.2 \%$ of the farmers provide supplementary feeds by spreading on the floor and $96.67 \%$ of the respondents offer supplementary feeds by throwing on the ground for the whole chickens together (100\%) reported, respectively [4, 3]. However, some of the farmers $23.8 \%$, use locally available feeding trough to provide supplementary feed.

Table 7. Methods of provision of supplementary feeds for chickens in the study district.

\begin{tabular}{|c|c|c|}
\hline \multirow{3}{*}{ Variables } & \multicolumn{2}{|c|}{ Study Area } \\
\hline & \multicolumn{2}{|c|}{ Pawe district } \\
\hline & Number & Percent \\
\hline \multicolumn{3}{|c|}{ Method of provision of supplementary feeds } \\
\hline Using locally prepared feeding trough & 19 & 23.8 \\
\hline Throwing on land to feed in groups & 61 & 76.2 \\
\hline \multicolumn{3}{|l|}{ Ways of feeding chickens } \\
\hline Group feeding & 68 & 85.0 \\
\hline Feeding by separate in age & 8 & 10.0 \\
\hline Feeding by separate in sex & 4 & 5.0 \\
\hline Feeding by separate in breed & - & - \\
\hline \multicolumn{3}{|c|}{ Mixing salt or limestone during grain supplements } \\
\hline Yes & - & - \\
\hline No & 80 & 100 \\
\hline
\end{tabular}

In study areas, all in all about $100 \%$ of the interviewed farmers were not adding salt or limestone when they offer grain supplement for chickens. This has its own effect on egg quality. Chickens which fed grains that have mineral deficiency might be produce eggs with thin egg shell or eggs without shell coverage. This is in agreement with the report that reported provision of mineral supplement was practiced only by few households (2.2\%) in Ada'a and Lume districts [7].

\subsubsection{Frequency of Watering Chickens}

In the families of $63.8 \%$ surveyed households' water is provided with free access for chickens in the study area (Table 8). On the other hand, about 27.5 and $8.7 \%$ of the respondents provide water for chickens twice a day (morning and evening time); and once per day (morning time only) in Pawe district. This result is at par with the report that reported $65.8,19.2$ and $15 \%$ of the respondents provided water for chickens twice/day, once/day and every other day, respectively without free access [4].

The main sources of water identified in the present study areas were rivers water, holes water and hand pump water. The majority $(73.75 \%)$ of the households in the study area obtained water from river, while $13.75 \%$ from holes and the rest $12.50 \%$ from hand pump water. This result is agreement with the finding that reported 90, 5.8 and $4.2 \%$ of the respondents obtained water for their chickens from river, rain and well water in Chelliya district, respectively [4].

As can be evident from the table, majority (72.5\%) of the respondents use part of plastic equipment as watering trough for their chicken, while $27.5 \%$ of the respondent used broken part of clay for watering trough. This result is in line with the result that reported $42.2 \%$ of the respondents use part ofplastic equipment to provide water for chickens [13].

Table 8. Frequency and source of water used for chickens in the study areas.

\begin{tabular}{|c|c|c|}
\hline \multirow{3}{*}{ Variables } & \multicolumn{2}{|c|}{ Study Area } \\
\hline & \multicolumn{2}{|c|}{ Pawe district } \\
\hline & Number & Percent \\
\hline \multicolumn{3}{|c|}{ Frequency of watering chickens } \\
\hline Free access & 51 & 63.8 \\
\hline Only morning & 7 & 8.7 \\
\hline Morning and evening & 22 & 27.5 \\
\hline \multicolumn{3}{|l|}{ Source of water for chickens } \\
\hline Hole water & 11 & 13.75 \\
\hline River & 59 & 73.75 \\
\hline Hand pump & 10 & 12.50 \\
\hline \multicolumn{3}{|c|}{ Water trough used for water provision of chickens } \\
\hline Broken part of clay & 22 & 27.5 \\
\hline Part of plastic equipments & 58 & 72.5 \\
\hline Purchased watering trough & - & - \\
\hline
\end{tabular}

\subsubsection{Chicken Housing Systems and Cleaning in the Study Area}

Type of housing has its own effect on chicken production and productivity. Can be noticed from the present study that about 55.0, 30.0, 10.0 and $5.0 \%$ of respondents share the same house with chickens, constructed separate house for chicken, kept in kitchen and kept on perch under the roof, respectively. Respondents didn't keep chickens in cage system in study area. This reflects adoption of modern chicken housing is weak in the study area. Similar proportions of housing methods report were reported that $53.3 \%$ of the respondents shared the same room with chickens, $33.3 \%$ constructed separate house for chicken and $13.3 \%$ of the respondents have different shelter during night in the same room for chickens [4]. But different proportions of housing methods report were reported that $58 \%$ of the surveyed households of mid-rift valley of Ethiopia keep chickens in main house, $26.6 \%$ on perch and $14 \%$ in separate sheds made for chickens [22].

As the farmers replied, majority of the chickens were kept in different types of house with people and utensils during the night and scavenge freely during the day, about $72.5 \%$ of the households clean the chickens' house daily, whereas $16.25 \%, 8.75 \%$ and $2.5 \%$ of the owners clean it weekly, once in two days and monthly, respectively (Table 9). Lack of frequent cleaning of chicken shelter might cause disease and increase morbidity and mortality rates of chicken. Thus, raising awareness of farmers on the need for cleaning shelters is important. In addition to diseases prevalence, the quality of the product obtained from dirty house is poor. Similarity reports have reported that $65.6 \%$ of surveyed households of East Gojjam clean chicken house daily [13]. Similarly, additional report also reported that majority of the respondent's clean chicken house/shelter daily (85.7\%), while the remaining (14.3\%) clean weekly in Amaro district of Ethiopia [12]. 
Table 9. Chicken housing system and frequency of cleaning in study areas.

\begin{tabular}{lll}
\hline & \multicolumn{2}{l}{ Study Area } \\
\cline { 2 - 3 } Variables & \multicolumn{2}{l}{ Pawe district } \\
\cline { 2 - 3 } & Number & Percent \\
\hline Chicken housing system & & \\
Share the same house with people & 44 & 55.0 \\
Separate house entirely constructed for chicken & 24 & 30.0 \\
Kept in kitchen & 8 & 10.0 \\
Kept on perch under the roof & 4 & 5.0 \\
Frequency of cleaning & & \\
Daily & 58 & 72.5 \\
Weekly & 13 & 16.25 \\
Monthly & 2 & 2.5 \\
Once in two days & 7 & 8.75 \\
\hline
\end{tabular}

\subsubsection{Chicken Health Management}

\section{(i). Major Diseases of Chicken in the Study Areas}

The major diseases of chicken in the study areas are shown in Table 10. Accordingly, the study showed that the major chicken diseases are Newcastle disease (NCD), fowl typhoid, infectious bronchitis, Gumboro and Marek's disease in their order of importance. This result clearly showed that there were many chicken diseases existing in the study district. It is obvious that disease impacts chicken production in many ways such as reduced body weight, reduced growth rate, low egg and meat production, low reproductive performance, high mortality and treatment cost. Poor housing, climatic condition, poor nutritional status and low level of management contributed to a high incidence of chicken diseases in the areas. On top of that the insufficient veterinary service and absence of scheduled vaccination seemed the major bottlenecks that need to be solved by concerned body to utilize the potential of the study areas. The problem chicken diseases raised in the study areas is in agreement with the report that reported Newcastle (Wararshe/Fengel), fowl cholera (cholera) and salmonella (kisen) were the major diseases affecting chickens in Amaro district, SNNPRS of Ethiopia [12]. Additional report also reported that the major diseases in order of their importance were $85 \%$ Newcastle disease (NCD) and 15\% other diseases (Coccidiosis, Fowl pox and Fowl typhoid) in Chelliya district [4].

Table 10. Major poultry diseases in the study district.

\begin{tabular}{lll}
\hline \multirow{2}{*}{ Variables } & \multicolumn{2}{l}{ Study Area } \\
\cline { 2 - 3 } & \multicolumn{2}{l}{ Pawe district } \\
\cline { 2 - 3 } & Number & Percent \\
\hline Diseases that mainly affect chickens & & \\
Newcastle diseases & 35 & 43.75 \\
Marek's disease & 4 & 5.0 \\
Fowl typhoid & 24 & 30.0 \\
Gumboro & 7 & 8.75 \\
Infectious bronchitis & 10 & 12.5 \\
\hline
\end{tabular}

\section{(ii) Sick Chicken Treatment and Places of Treatment in the} Study Areas

It was noticed from the present study that, majority of the sample household respondents had different treatment methods when sick birds observed in the flock. Accordingly, majority $(86.25 \%)$ of the respondents reported that they medicate sick chickens in pawe district. However, about $5.00 \%$ and $8.75 \%$ of the surveyed household reported that selling and isolation of sick chickens in the study area. Similarity report reported that the measures taken by farmers when sick chickens observed in the flock were medication (90\%), selling (6.8\%) and isolation of chicken (3.2\%) [18].

The majority of farmers reported that they have treatment places when their chicken is sick in the flock. Thus, of the total households $42.50 \%$ of the respondents were treated sick chickens at home by traditional treatment methods. The respondents used traditional treatment due to lack of enough knowledge about the advantage of modern drug, accessibility and low prices of traditional treatment and unavailability of veterinary services at their locality.

But those farmers who know the negative effect of traditional treatment on the health of chickens treated at animal health posts and veterinary clinics. Therefore, about $32.50 \%$ of the respondents reported that they treat sick chicken at animal health post (health institution organized at kebele level) and $11.25 \%$ of the respondents treat at veterinary clinics (health institution organized at woreda level).

Table 11. Sick chicken treatment and places of chicken treatment.

\begin{tabular}{lll}
\hline & \multicolumn{2}{l}{ Study Area } \\
\cline { 2 - 3 } Variables & \multicolumn{2}{l}{ Pawe district } \\
\cline { 2 - 3 } & Number & Percent \\
\hline Measures against diseases & 69 & 86.25 \\
Medication & 4 & 5.00 \\
Selling & 7 & 8.75 \\
Isolation & & \\
Place of sick chickens' treatments & 26 & 32.50 \\
Animal health post (kebele level) & 9 & 11.25 \\
Veterinary clinic (woreda level) & 34 & 42.50 \\
At home by traditional medicine & & \\
Traditional material used for treatment & 4 & 5.00 \\
Juice of Eucalyptus leaf & 3 & 3.75 \\
Juice of Demakese leaf & 8 & 10.00 \\
Lemon Juice & 7 & 8.75 \\
Katikala & 12 & 15.00 \\
Garlic & & \\
Traditional treatment methods & 10 & 12.50 \\
Orally in liquid form & 23 & 28.75 \\
Mixing with injera & 1 & 1.25 \\
Smoking & & \\
\hline
\end{tabular}

The traditional materials used for treatment of sick chickens reported by household respondents were garlic (nech shunkurt), lemon juices (lome chemek), local beverage (araqee/Katikala), Juice of Eucalyptus leaf and Juice of Demakese leaf in the study area. Other respondents reported pepper powder as traditional drug to treat their chickens. According to the response of the household respondents, the amount of traditional drug used for sick chicken treatment was not measured and known. This might have impact on the health status of the chickens. In addition to traditional treatment, some respondents used treatments ordered for human being for sick chickens. The current result is in line with the report that reported farmers in mid rift valley of 
Oromia, use garlic, different green leaves like "Bala Ganate", lemon, local alcohol, paper powder, butter as drenching, nasal application and smoking to treat sick chickens [22]. Additional report also reported that the provision of a mixture of local alcohol ("Arekie"), lemon and onion to sick birds against NCD was the most widely used type of traditional treatment [8].

Among traditional users of the study area (28.75\%) administer traditional treatment for sick chickens by mixing with injera (human food) while $12.50 \%$ of respondents of the study area traditional treatment for sick chickens orally in liquid. Only very few farmers $(1.25 \%)$ from the study area reported provision of traditional treatment through smoking for chickens.

\subsection{Reproductive and Production Performance of Chickens in Study Areas}

\subsubsection{Age at First Egg Laying}

In the study areas, the average age at first egg laying for the local chickens $(6.18 \pm 0.024$ month) (Table 12). The current result is concurred with the report that reported 6 months of age at first egg laying for local chicken breeds in Debsan Tikara kebele at Gondar Zuria Woreda, North Gondar [15]. Additional report that reported 6.5 months of age at first egg laying for local chickens in Halaba district of southern Ethiopia [18]. Another report also reported that higher value ( 7 months) of age at first egg laying for indigenous chicken breeds at Enebsie Sar Midir woreda of Eastern Gojjam [14].

\subsubsection{Egg Production and Numbers of Eggs Per Clutch}

The result of the present study showed the average egg production of the local chicken breeds $(60 \pm 0.123)$ in the study area (Table 12). The average egg yield (60 eggs per hen /year) for local chicken was almost equal to the result that reported an average of 65 eggs per local hen/year at 33 Enebsie Sar Midir woreda of Eastern Gojjam [14]. But the average eggs yield in the current study was greater than the report that reported an average of 43.84 eggs per local hen/year for Gomma woreda [16]. And by far lower than the average egg yield report that reported 155.2 eggs/local hen/year for Chelliya district of west Shewa zone [4]. The reason for this variation might be the difference in management practices of the farmers in different districts.

In the study districts, the average number of eggs per clutch was 14.28 eggs for local chicken breeds. This result is almost similar with the findings that reported 13 eggs per hen /clutch [15]. Additional report that reported 14 eggs per hen/ clutch for local chickens [22]. But this result is lower than the report that reported 18 eggs per clutch for local chickens [13].

\subsubsection{Number of Eggs Set Per Hen and Hatchability of Eggs in the Study Areas}

The respondents revealed that exclusively natural incubation and hatching was practiced by all $(100 \%)$ chicken producers in the study area. The average number of eggs set for incubation was $10.65 \pm 0.03$ per hen, from which relatively fair percentage of chicks $(81.50 \%)$ was hatched from local chickens. This result is in line with report that reported average number of eggs set per local hen was 13.2 eggs with $82.83 \%$ hatchability [13]. Another report also reported that the average number of eggs set per local hen was 12 with $83.7 \%$ hatchability for local breeds [18]. But the current hatchability reported was lower than the report that reported average number of eggs set per hen as 10.95 with $87.29 \%$ hatchability in Northern Gondar [29]. This is by far greater than $59.6 \%$ and $72 \%$ hatchability from 13 and 10 average number of eggs set for incubation under local chickens, respectively $[14,15]$.

\subsubsection{Mortality Rate of Chickens in the Study Areas}

In the study areas, high proportion of chicken mortality up to age of 8 weeks was reported by respondents which might indicate high prevalence of chickens diseases and predators. The mortality for local chickens (35.36\%) (Table 12). Even though the mortality rate was too high for the current study, it is lower than the report that reported $41 \%$ of mortality rate for Gomma district [16]. In general, the result indicates that there is an urgent and great need to intervene and reduce chickens mortality in the study areas.

Table 12. Reproduction and production performance of local chickens in the study areas.

\begin{tabular}{ll}
\hline & Study Area \\
\cline { 2 - 2 } Parameters & Pawe district \\
\cline { 2 - 2 } & Local chickens \\
\cline { 2 - 2 } & Mean \pm SE \\
\hline Age at first laying eggs (month) & $6.18 \pm 0.024$ \\
Number of eggs per year & $60 \pm 0.123$ \\
Number of eggs per clutch & $14.28 \pm 0.05$ \\
Clutch size & $4.40 \pm 0.019$ \\
Numbers of eggs set per hen & $10.65 \pm 0.03$ \\
Chicks hatched from set eggs & $8.68 \pm 0.06$ \\
Hatchability (\%) & 81.50 \\
Chicks survived up to age of 8 weeks & $5.63 \pm 0.06$ \\
Survival rate up to age of 8 weeks $(\%)$ & 64.86 \\
Mortality rate up to age of 8 weeks $(\%)$ & 35.36 \\
Age of cockerels for breeding (month) & $5.32 \pm 0.02$ \\
\hline
\end{tabular}

\section{Conclusions}

The study was conducted with the overall objective to assess of Chicken production systems and identify the productivity performance related to chicken production under village/traditional production system in pawe district of Beneshangul Gumuz Regional State, Ethiopia. A total of 80 respondents were purposively selected from four purposively selected kebeles in the study areas. All the data collected were analyzed using SPSS version 20.

Results of the study revealed that the average flock size of local chickens was $(13.8 \pm 0.20)$ per household in the study area. In the study areas, the average age at first laying egg for the local chickens was $(6.18 \pm 0.024$ month $)$. The survey indicated that the average egg production of the local chicken breeds was $(60 \pm 0.123$ eggs per hen per year). The study revealed that the average number of eggs set for 
brooding/incubation was $10.65 \pm 0.03$ per hen, from which relatively fair percentage of chicks $(81.50 \%)$ was hatched from local chickens. In the study areas, high proportion of chicken mortality up to age of 8 weeks was revealed by respondents which might indicate high prevalence of chickens diseases and predators.

The study also revealed that the main feed of chicken in the study areas are scavenging with additional supplements. But only few of the respondents use homemade feed chicken feed.

The major chicken diseases reported in pawe district in the order of their importance were New Castle Disease, fowl typhoid, Infectious bronchitis; Gumboro and Marek's disease were reported to be the major diseases of chicken.

In general, it can be concluded that the productivity performance of local chicken breeds was better comparatively to the given production system and management in the study areas. More ever the performance of local chickens under village production system could be increased through improved breeding, housing, feeding and health management.

\section{References}

[1] Aberra Melesse. 2000. Comparative studies on performance and physiological responses of Ethiopian indigenous ("Angete-melata") chicken and their F1 crosses to long term heat stress. Ph.D Thesis. Martin-Luther University, HalleWittenberg, Berlin. pp: 4-5.

[2] Abubakar, M. B, A. G. Ambali and T. Tamjdo. 2007. Rural Chicken Production: Effects of Gender on Ownership, and Management Responsibilities in Some Parts of Nigeria and Cameroon. International Journal of Poultry Science 6 (6): 413416.

[3] Addis, G., and Malede, B. 2014. Chicken Production Systems, Performance and Associated Constraints in North Gondar Zone, Ethiopia. J. Fisheries Lives. Prod. 2: 115-118.

[4] Bikila Negari. 2013. Study of Production Practices, Productivity, and Egg Quality of Village Chicken in Chelliya District Western Shewa, Ethiopia. An Msc thesis, presented to the school of graduate studies of Haramaya University, Ethiopia. 81p.

[5] CSA (central statistical Agency). 2015. Agricultural sample survey volume II report on livestock and livestock characteristics Addis Ababa August 2015573 statical bulletin 573 .

[6] Dawit A. Tamrat, D., Stotaw, F., Nzietcheung, S. and Roy, D. 2008: Overview and background paperon Ethiopia's poultry sector. Relevance for HPAI Research in Ethiopia. www.h pairesearch net. Accessed 06 April 2011.

[7] Desalew Tadesse. 2012. Management practices, productive performance and egg quality traits of exotic chickens under village production system in east Shewa, Ethiopia. An Msc thesis, presented to the school of graduate studies of Addis Ababa University. 70p.

[8] Fisseha Moges, Abera Mellesse and Tadelle Dessie. 2010. Assessment of village chicken production system and evaluation of the productive and reproductive performance of local chicken ecotype in Bure district, North West Ethiopia. African J. Agri. Res., 5 (13): 1739-1748.

[9] Halima Hassen Mogesse. 2007. Phenotypic and genetic characterization of indigenous chicken populations in NorthWest Ethiopia. Ph.D Thesis. Submitted to the faculty of natural and agricultural sciences department of animal, wildlife and grassland Sciences. University of the Free State, Bloemfontein, South Africa.

[10] Hellin, J., A. Griffith \& A. Mike. 2005. Mapping the market: Market-literacy for agricultural research \& policy to tackle rural poverty in Africa. In: Proceedings of an International Seminar, $28^{\text {th }}$ February $1^{\text {st }}$ March 2005, Westminster, London, UK, $110-150$.

[11] Khalafalla, A. I., S. Awad and W. Hass. 2001. Village poultry production in the Sudan. Department of Microbiology, Faculty of Veterinary Science, University of Khartoum, Khartoum North, Sudan. Department of Microbiology, Faculty of Veterinary Science, University of Khartoum, Khartoum North, Sudan. Accessed on 25th August, 2007.

[12] Matiwos Habte, Selamawit Debele, Birhanu Admassu and Asmamaw Yinnessu. 2015. Village chickens production performance assessment under scavenging management system in Amaro Districts of SNNPRS of Ethiopia. Wudpecker J. Agri. Res., 4 (3): 021-034.

[13] Melese Gashu and Melkamu Bezabih. 2014. Assessment of chicken production under farmer"s management condition in East Gojjam Zone, Amhara Regional State, Ethiopia. Greener J. Anim. Breeding and Genetics, 1 (1): 001-010.

[14] Melkamu Bezabih and Andargie Zewudu. 2013. Performance evaluation of local chicken at Enebsie Sar Midir Woreda, Eastern Gojjam, Ethiopia. Unique res. J. of Agri. Sci., 1 (2): 006-010.

[15] Melkamu Bezabih and Wube Atalel. 2013. Constraints and Opportunities of Village Chicken Production in Debsan TiKara Keble at Gonder Zuria Woreda, North Gonder, Ethiopia. International J. of Sci. and res. Publications, 3 (9): 8 .

[16] Meseret, M. 2010. Characterization of village chicken production and marketing system in Gomma woreda, Jimma zone, Ethiopia. An Msc Thesis, presented to the school of graduate studies of Jimma University, Ethiopia. 110p.

[17] Moreda, E., S Hareppal, A Johansson, T Sisaye and Z Sahile. 2013. Characteristics of Indigenous Chicken Production System in South West and South Part of Ethiopia. British J. of Poult. Sci., 2 (3): 25-32.

[18] Nebiyu Yemane, Berhan Tamir and Kelay Belihu. 2013. Characterization of village chicken production performance under scavenging system in Halaba districts of southern Ethiopia. Ethiop. Vet. J. 17 (1): 69-80.

[19] Nigussie, D., Liesbeth, H., van der Waaij, Tadelle D., Johan A. M. van Arendonk. 2010. Production objectives and trait preferences of village poultry producers of Ethiopia: implications for designing breeding schemes utilizing indigenous chicken genetic resources. Trop. Anim. Health Prod., 42: 1519-1529.

[20] Pedersen C. 2002. Production of semi-scavenging chickens in Zimbabwe. PhD thesis. Royal Veterinary and Agricultural University, Copenhagen, Denmark. 213 pp. 
[21] Salam Kondombo, R. 2005. Improvement of village chicken production in a mixed (chickenram) arming system in Burkina Faso. Ph.D Thesis. Wageningen Institute of Animal Sciences, Animal Nutrition Group, Wageningen University, the Netherlands.

[22] Samson Leta and Endalew Bekana. 2010. Survey on Village Based Chicken Production and Utilization System in Mid Rift Valley of Oromia, Ethiopia. Global Vet., 5 (4): 198-203.

[23] Statistical Packages for Social Sciences (SPSS). 2002. SPSS 12 for Windows. SPSS Inc. Chicago, Illinois.

[24] Tadelle, D. 2004. Effect of scavenging on diet selection and performance of RIR and Fayomi breeds of chicken offered a choice of Energy and Protein Feeds.

[25] Tadelle, D. and B. Ogle, 2001. Village poultry production systems in the central high lands of Ethiopia. Tropical Animal Health and Production, 33 (6): 521-537.
[26] Tadelle, D., 1996. Studies on village poultry production systems in the central highlands of Ethiopia. M.Sc. Thesis, Swedish University of Agricultural Sciences. Uppsala, Sweden.

[27] Tadelle, D., 2003. Phenotypic and genetic characterization of local ecotypes in Ethiopia. PhD Thesis, Humboldt University of Berlin, Germany.

[28] Tadelle, D., T. Million, Alemu Yami \& K. J. Peters. 2003. Village chicken production systems in Ethiopia: Use patterns \& performance valuation and chicken products \& socioeconomic functions of chicken. Livestock Research for Rural Development 15 (1).

[29] Wondu Mamo, Mehiret Melaku, and Berhan Tamir. 2013. Characterization of Urban Poultry Production System in Northern Gondar, Amhara Regional State, Ethiopia. Agri. Biol. J. N. Anim., 4 (3): 192-198. 